\title{
Freedom of movement for workers
}

\section{Relaxing immigration restrictions could greatly improve the well- being of people in developing countries, with little effect on wages}

Keywords: migration, open borders, movement of workers, poverty

\section{ELEVATOR PITCH}

Most developed countries have foreign aid programs that aim to alleviate poverty and foster economic growth in less developed countries, but with very limited success. A large body of evidence indicates that the root of the economic development problem is cross-country differences in the productivity of labor. If workers are much more productive in one country than in another, the obvious way to help people in less developed countries is to allow them to help themselves by moving to places where they can be more productive. Yet immigration laws severely constrain such movement.

\section{KEY FINDINGS}

\section{Pros}

( Immigrants can greatly improve their standard of living, even after allowing for the costs of living away from home.

๑ If workers are much more productive in one country than in another, lifting the restrictions on immigration would produce large efficiency gains.

$\oplus$ The estimated net gains from open borders are about the same as the gains from a growth miracle that more than doubles incomes in lessdeveloped countries.
Open borders could more than double the average income in less developed countries

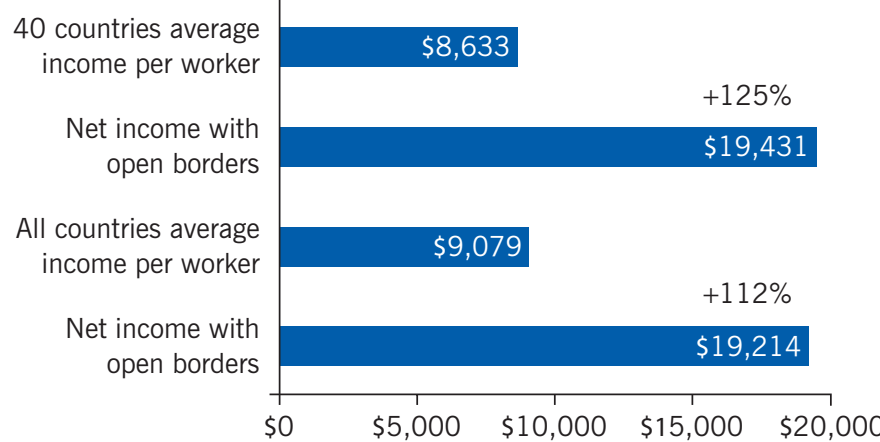

Source: From [1] using data from [2] and differences in income per worker from Penn World Table version 7.1.

\section{Cons}

- Immigrants are a burden on the social welfare system.

- Immigrants "are not like us"-a loss of national identity is associated with large inflows of immigrants.

\section{AUTHOR'S MAIN MESSAGE}

Allowing workers to move freely across countries could yield large gains, comparable to a doubling of labor income in developing countries. Although the immigrant flows would be large, the wage effects would be small since increases in labor supply would induce investment. So for policymakers wanting to increase the welfare of the average person without regard to nationality, relaxing immigration restrictions could greatly improve the well-being of people in developing countries. And some of the large gains accruing to immigrants could be used to pay for whatever costs are imposed on incumbent workers-for example by levying an income tax surcharge on recent immigrants. 


\section{MOTIVATION}

Economics has little to say about the relationship between immigration and national (or cultural) identities. There is much to be said about how immigrants might be integrated into social welfare systems without imposing an undue burden on current participants, but that is not pursued here. Instead, the main point of this paper is to summarize the economic gains enjoyed by immigrants and the effects of free migration on the wages of all workers.

An important political impediment to the relaxation of immigration restrictions is the obvious fact that potential immigrants do not have any say in the matter. A global referendum on whether people should be allowed to move freely across international borders might very well pass with a substantial majority. But in practice the voters in developed (democratic) countries generally oppose free movement, and the votes of those who wish to move do not count.

\section{DISCUSSION OF PROS AND CONS}

The estimated gains from allowing free labor movement across national borders if all restrictions were lifted would be roughly equivalent to a sudden spurt of economic growth that doubled the average income of people in less developed countries.

\section{The costs of immigration restrictions}

Quantitative analyses of the costs of immigration restrictions have been based on the standard textbook model of a segmented labor market (see Figure 1) [3], [4], [5].

Figure 1. Standard model of a segmented labor market

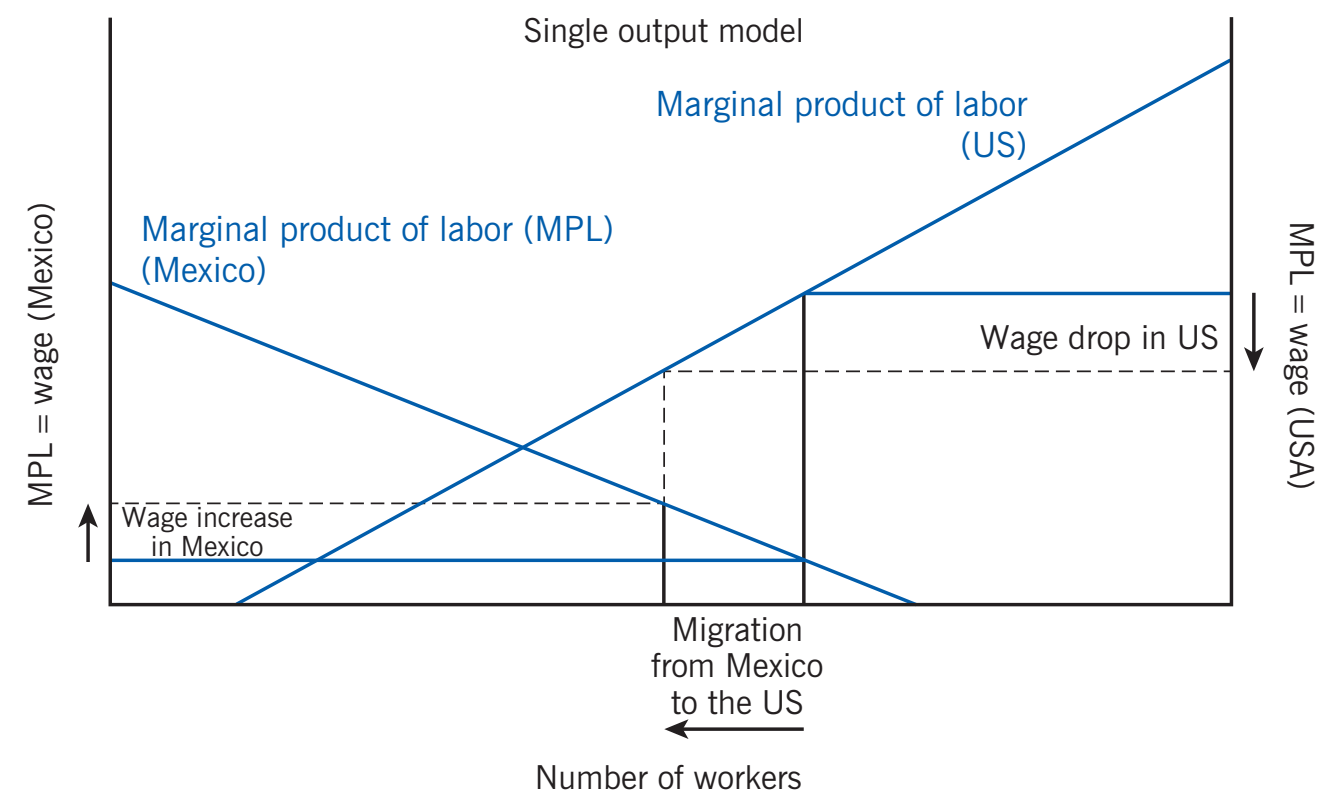

Note: The number of workers in Mexico is measured from left to right and in the US from right to left.

Source: Author's own. 
Figure 1 shows how wages are affected by migration in a model with a fixed number of workers distributed over two locations (Mexico and the US) with diminishing returns to labor, assuming that the same product is produced in both countries. As the number of workers within a country increases, each additional worker is less productive (the marginal product of labor is diminishing), as shown by the downward sloping curve for Mexico, where the number of workers in Mexico is read from left to right. There is a similar downward-sloping curve for the US, shown in the diagram as a mirror image, with the number of workers counted from right to left.

If two labor markets (say, Mexico and the US) have different downward-sloping curves showing the marginal product of labor as a function of the number of workers employed, then migration from Mexico to the US reduces the wage in the US and increases the wage in Mexico and raises total output. The result when immigration restrictions are removed is at the point where marginal products are equal and total output is maximal [3].

This segmented labor market model has two major limitations for the discussion here.

- One is that the people in the model are not attached to any particular place, whereas a great deal of evidence indicates that, other things equal, most people would rather live their lives in the country where they grew up. Thus, in the absence of immigration restrictions, one would not expect that wages would be equalized across countries, but that in the new equilibrium, every potential migrant would view the wage gain from moving to a high-wage country as insufficient to offset the cost of living away from home.

- The second limitation is that there is no consideration of the extent to which international wage differences are indirectly arbitraged through trade in product markets (meaning that low-wage countries should be able to undercut high-wage countries in international product markets).

The gains from migration can instead be attributed to differences in labor productivity (as opposed to differences in the numbers of workers allocated to each country) [6]. In this case, the interpretation is that workers are less productive in less developed countries. The reasons for these differences are not well understood [1], and attempts to improve productivity in less developed countries through foreign aid have not been notably successful. But without allowing for differences in worker productivity, it is hard to see how the huge observed differences in wage rates can coexist with relatively free mobility of the goods that workers produce.

On the other hand, if there are cross-country differences in worker productivity, then arbitrage in the product markets equalizes wages across countries when labor is measured in efficiency units [7]. A worker becomes more productive simply by moving from a country where it is relatively difficult to work efficiently to a country where labor is more efficient. But the cost of labor is the same in both countries from the point of view of an employer, since the difference in efficiency is fully reflected in the wage. This resolves the apparent discrepancy between production costs across countries, so that the coexistence of large measured wage differences and relatively free mobility of products is no longer puzzling.

In this case, the gains from migration have nothing to do with reallocating capital across countries, because it is assumed that there are no cross-country differences in the 
productivity of capital, and factor price equalization implies that the return to capital is the same in all countries [1], [8]. Indeed, the data on cross-country differences in the return to capital do not look at all like the wage data [8]; in particular, the measured return to capital in the US is not systematically higher than returns to capital in less developed countries.

\section{Migration choices with open borders}

An illustrative example of labor markets with open borders can be given using data on the proportion of Puerto Ricans who choose to stay in Puerto Rico, even though the US border is open to them and wages are considerably higher in the US than in Puerto Rico (Figure 2). Similarly, the flow of immigrants from Poland to the existing EU countries after Poland joined the EU in May 2004 was surprisingly small. The peak flow of "permanent" migrants occurred in 2006 , when about 47,000 people emigratedand about 38 million people did not [2].

Figure 2. Education, wages, and migration in Puerto Rico and the US for men aged 20-64 who were born in Puerto Rico, 2000

\begin{tabular}{|c|c|c|c|c|c|c|c|}
\hline \multirow[b]{2}{*}{ Item } & \multicolumn{7}{|c|}{ Years of schooling } \\
\hline & $0-9$ & $9-11$ & 12 & $13-15$ & 16 & 17 & $9-17$ \\
\hline $\begin{array}{l}\text { Wage ratio, } \\
\text { Puerto Rico/US }\end{array}$ & 0.46 & 0.49 & 0.53 & 0.60 & 0.67 & 0.72 & 0.57 \\
\hline $\begin{array}{l}\text { Percentage who } \\
\text { stay in Puerto Rico }\end{array}$ & 68 & 53 & 62 & 69 & 73 & 64 & 64 \\
\hline $\begin{array}{l}\text { Number of } \\
\text { observations }\end{array}$ & 218,715 & 203,138 & 515,421 & 254,483 & 134,023 & 56,929 & $1,070,231$ \\
\hline
\end{tabular}

Source: Author's calculations based on data from US Census 2000 and Ruggles, S., J. T. Alexander, K. Genadek, R. Goeken, M. B. Schroeder, and M. Sobek. Integrated Public Use Microdata Series: Version 5.0 [Machine-readable database]. Minneapolis: University of Minnesota, 2010 [9].

The (proportional) wage gap between Puerto Rico and the US is large (the gap is largest for men without much formal schooling). But the proportion choosing to migrate to the US is generally well below $50 \%$, despite the large wage differences (Figure 3 ). This clearly shows that, other things being equal (and even not so equal), people would generally prefer to live at home rather than move to a new place. This is evident even in internal migration data. And migration to a new country of course involves substantial costs, including in many cases the difficulty of adjusting to a new language and a different cultural environment. 
Figure 3. Wages and migration: Puerto Rico and the US
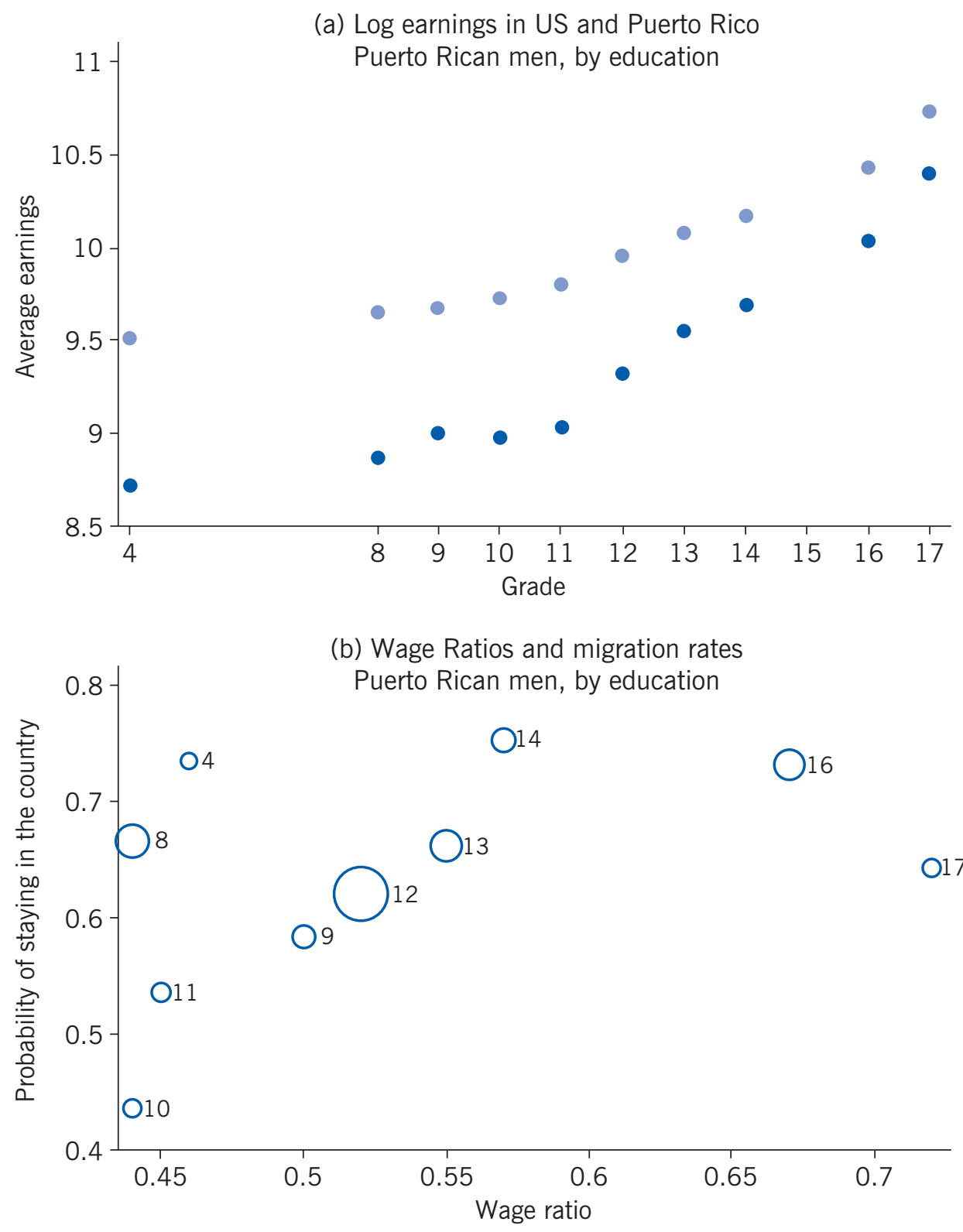

Note: (a) Light circles denote Puerto Rican men in the US and dark circles in Puerto Rico. (b) Numbered circles are scaled by the number of people at each level.

Source: Author's calculations based on data from US Census 2000 and Ruggles, S., J. T. Alexander, K. Genadek, R. Goeken, M. B. Schroeder, and M. Sobek. Integrated Public Use Microdata Series: Version 5.0 [Machine-readable database]. Minneapolis: University of Minnesota, 2010 [9].

\section{Gains from free movement of labor}

Relative wages can be used to measure cross-country differences in labor efficiencythat is, differences in the productivity of a given stock of human capital, when moved from one country to another [10], [11]. For example, the wage of a Mexican worker in 
Mexico is about $40 \%$ of the wage of a worker with the same education and experience who was born and educated in Mexico but working in the US in the 2000 Census. This means that Mexican workers have 0.4 efficiency units of labor (per unit of human capital), so a Mexican worker who crosses the US border becomes as productive as 2.5 Mexican workers who stayed at home. The assumption here is that the variables that reduce labor productivity in Mexico (whatever they might be) are specific to the location and not to the people who work in that location [1].

When a worker moves from a low-productivity country to a high-productivity country, the (gross) income gain is the increase in productivity (Figure 4). But this overstates the gain from migration. A great deal of evidence indicates that, other things being equal, most people would rather live their lives in the country in which they grew up. Thus, in the absence of immigration restrictions, one would not expect wages to be equalized across countries; rather, in the new equilibrium, many people would choose not to migrate, viewing the wage gain from moving to a high-wage country as insufficient to offset the cost of living away from home.

Figure 4. Cross-country differences in wages relative to wages of similar workers

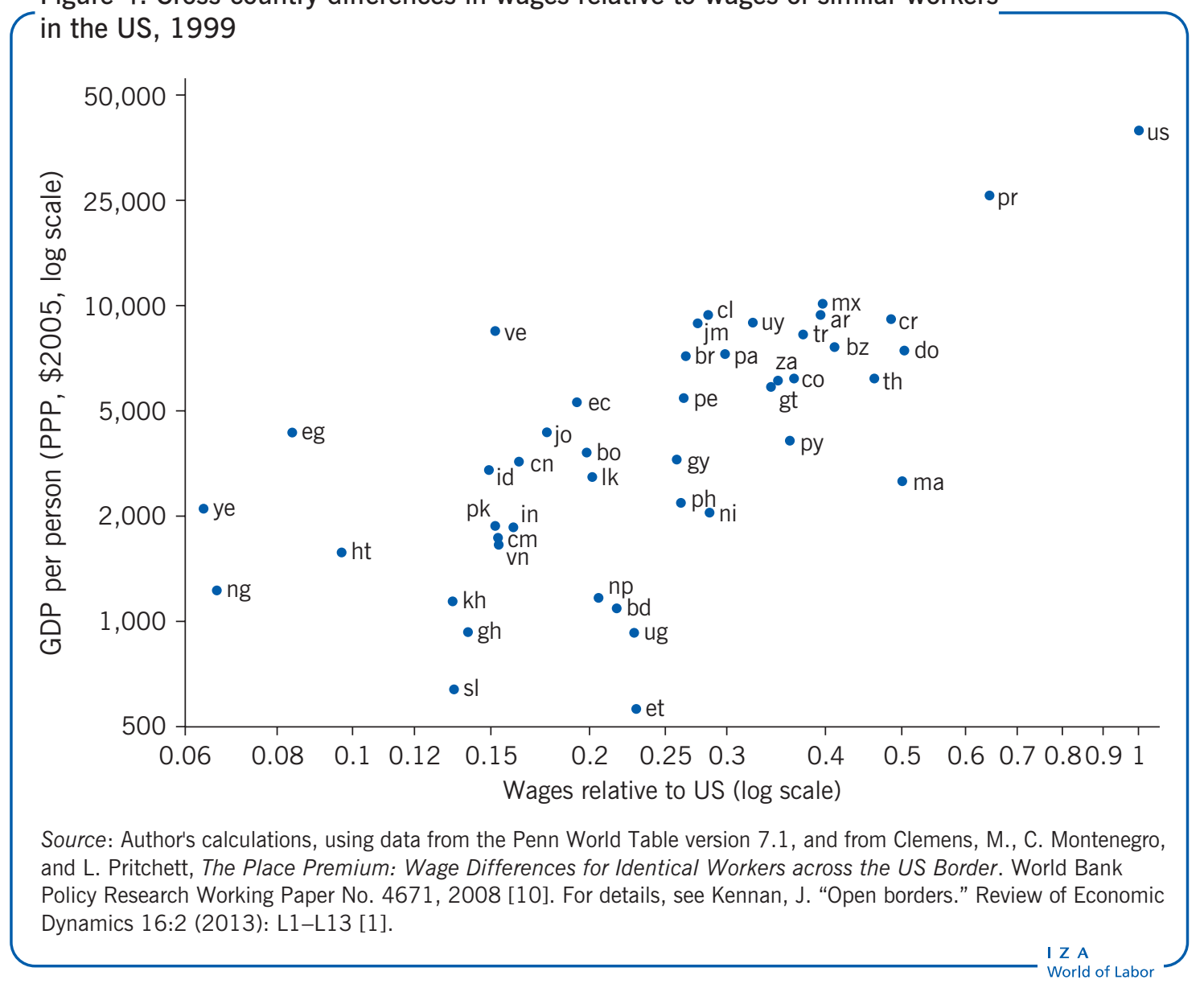

The net gains from migration differ from one individual to another, depending on the strength of the individual's attachment to the home country (for example, the strength of family ties). The net gain for the marginal migrant is zero, and of course there is no 
gain for those who do not migrate. If the lowest migration cost is zero, then the first person who moves gains the full income difference. For the average migrant, the gain is roughly half this difference [1].

The average net gain from open borders for 40 countries is estimated at $\$ 10,798$ per worker (including nonmigrants) per year (in 2012 dollars, adjusted for purchasing power parity-please see Figure 5) [1]. This is a very large number: the average income per worker in these countries is $\$ 8,633$, so the gain in (net) income is $125 \%$. These estimates can be expanded to cover virtually all countries (although this entails the use of more questionable relative productivity estimates). The estimated gain is then $\$ 10,135$, relative to an average income of $\$ 9,079$, so the gain is $112 \%$. These are of course just rough estimates, relying on several strong simplifying assumptions. But unless these assumptions are extremely far off the mark, the results indicate that the gains from open borders would be enormous [1].

Figure 5. Net gains per worker from open borders in 40 countries

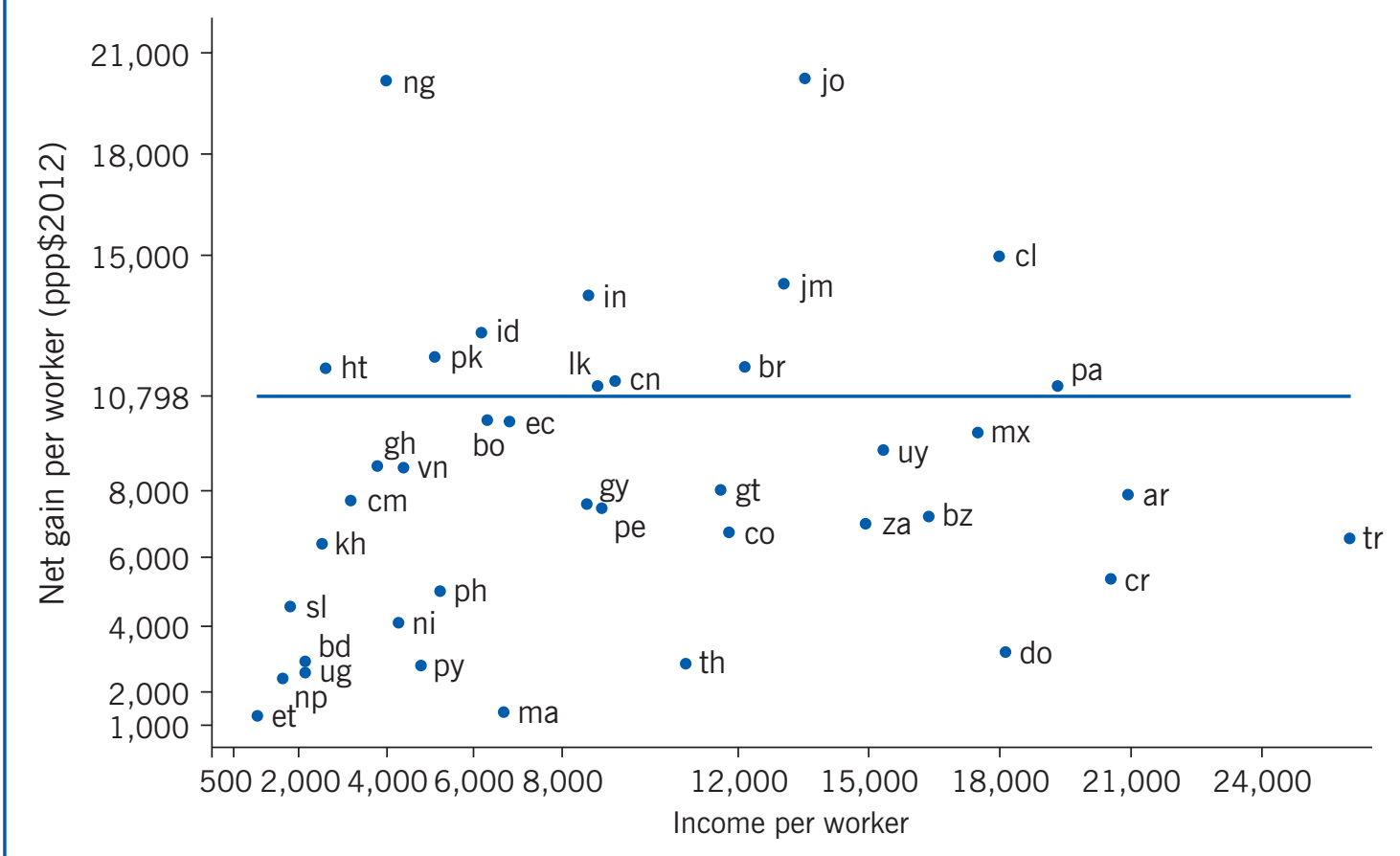

Source: Author's calculations, using data from the Penn World Table version 7.1, and from Clemens, M., C. Montenegro, and L. Pritchett, The Place Premium: Wage Differences for Identical Workers across the US Border. World Bank Policy Research Working Paper No. 4671, 2008 [10]. For details, see Kennan, J. "Open borders." Review of Economic Dynamics 16:2 (2013): L1-L13 [1].

\section{Wage effects of immigration in the host country}

As mentioned, a standard argument against the relaxation of immigration restrictions is that a large inflow of immigrants is likely to depress wages in the host country. Although this proposition seems like common sense, the logic of the argument is flawed. The empirical evidence suggests that large immigrant flows have not in fact led to substantial effects on wages (except perhaps for the wages of previous immigrants) [12]. Given a constant returns technology, with rapid adjustment of capital stocks in 
response to changes in the supply of labor, even large increases in immigration have small effects on wages [12]. Immigration nevertheless leads to adjustments in spatial wage differentials, due largely to the tendency of immigrants to move to cities that already have many immigrants, combined with a strong tendency of native workers to stay in the place where they were born.

As a logical matter, the argument that immigration depresses wages is basically that there are diminishing returns to labor: as more workers are added, the incremental contribution of each worker falls. This is fine if nothing else changes-no new factories, no new investment-so that there is less capital available for each worker. But this would mean that there is a strong incentive to invest more. That is, the other side of the coin is that there are more workers for each piece of capital, so to the extent that immigration tends to depress wages, it tends to stimulate investment, restoring wages to their original level.

Investment involves forgoing current consumption to free up resources to produce machines that will increase future output, augmenting future consumption. This involves a balance between impatience and the return on investment, and an increase in the number of workers tilts the balance toward more investment. Eventually the amount of capital available increases in proportion to the number of workers, restoring the balance. The implication in the long term is that immigration has no lasting effect on wages.

This raises the question of how long it takes for investment to catch up with the flow of new immigrants. But the evidence indicates that migration is a slow process. For example, evidence on internal migration in the US suggests that the responses to spatial wage differences are distributed over a period of many years [13]. In any case, immigration restrictions could be relaxed gradually, allowing ample time for investment to catch up.

In the short term, the effect of free immigration on wages is determined by the increase in the effective supply of labor on the world market-from workers moving to countries where they are more productive. It is assumed here that immigrant and native born workers are perfect substitutes, given their respective skill levels. The magnitude of this effect can be roughly estimated under plausible assumptions about how willing people are to move away from their home countries to increase their income. The effective labor supply without migration is estimated as the equivalent of about 800 million US workers, implying that the US labor force supplies about $20 \%$ of the effective labor in the world market. With open borders, the effective labor supply in the world market roughly doubles (implying that the US labor force would then account for about $10 \%$ of the total, not counting immigrants). Although this is obviously a very large change in the supply of labor, the estimated effect of open borders on real wage rates is surprisingly small (even in the short term, with capital held fixed). Under standard assumptions about technology and income shares, the real wage would fall by only about $20 \%$ if everyone moved immediately, with no time for adjustment of the capital stock [1].

\section{LIMITATIONS AND GAPS}

A major gap in the economics literature is that there has been little work on the practical implementation of more liberal immigration policies. In principle, it should 
be possible to manage the adjustment to a world with open borders in such a way that the investment stimulated by the increased efficiency of labor keeps pace with the migration flows, thus eliminating the negative effects on real wages. More research is needed to provide some guidance on a realistic time scale.

\section{SUMMARY AND POLICY ADVICE}

Proposals to relax restrictions on immigration are generally unpopular, in part because economists have failed to explain the enormous social losses associated with these restrictions and the fairly small labor market effects of free migration. Reasonable estimates of the welfare gains from allowing workers to move freely across countries indicate an order of magnitude comparable to doubling the annual income of a typical worker in a less developed country. It is important to recognize that many people would choose not to migrate, because they prefer to live in their home country even if their income would be much higher elsewhere. Thus migration entails a substantial cost (and the welfare gain is measured net of this cost). But the flow of immigrants under open borders would be very large, and one might then expect large decreases in wages in the destination countries. In fact, the estimated wage effects are surprisingly small, even if everyone moves immediately. Increases in the effective labor supply provide a powerful incentive to invest, and if the flow of new investment keeps pace with the immigrant flows, there is no fall in wages.

The policy implications are clear, at least from the perspective of someone concerned with the welfare of the average person, without regard to nationality: Relaxing restrictions on immigration could greatly improve the well-being of people in less developed countries. Adjusting to a world with open borders could in principle be managed so that the investment stimulated by the greater efficiency of labor keeps pace with migration flows, thus eliminating the downward pressure on wages.

The resistance to free migration in receiving countries would be reduced if all borders were open, so that the large immigrant inflows are spread over many countries. A better understanding of the economic effects of free migration would also lessen resistance. And some of the large gains accruing to immigrants could be used to pay for whatever costs are imposed on incumbent workers-for example by levying an income tax surcharge on recent immigrants.

\section{Acknowledgments}

The author thanks two anonymous referees and the IZA World of Labor editors for many helpful suggestions on earlier drafts.

\section{Competing interests}

The IZA World of Labor project is committed to the IZA Guiding Principles of Research Integrity. The author declares to have observed these principles.

(c) John Kennan 


\section{REFERENCES}

\section{Further reading}

Clemens, M. A. "Economics and emigration: Trillion-dollar bills on the sidewalk?" Journal of Economic Perspectives 25:3 (2011): 83-106.

Hanson, G. H. "International migration and human rights." In: Hite, K., and M. Unger (eds). Sustaining Human Rights in the Twenty-First Century. Baltimore, MD: The Johns Hopkins University Press, 2013; pp. 245-266.

\section{Key references}

[1] Kennan, J. “Open borders.” Review of Economic Dynamics 16:2 (2013): L1-L13.

[2] Poland Central Statistical Office. Demographic Yearbook of Poland. Warsaw: Poland Central Statistical Office, 2013.

[3] Hamilton, B., and J. Whalley. "Efficiency and distributional implications of global restrictions on labour mobility: Calculations and policy implications." Journal of Development Economics 14:1 (1984): 61-75.

[4] Moses, J. W., and B. Letnes. "The economic costs to international labor restrictions: Revisiting the empirical discussion." World Development 32:10 (2004): 1609-1626.

[5] Iregui, A. M. Efficiency Gains from the Elimination of Global Restrictions on Labour Mobility: An Analysis Using a Multiregional CGE Model. Banco de La Republica Working Paper No. 146, 2000.

[6] Klein, P., and G. Ventura. "Productivity differences and the dynamic effects of labor movements." Journal of Monetary Economics 56:8 (2009): 1059-1073.

[7] Trefler, D. "International factor price differences: Leontief was right!" Journal of Political Economy 101:6 (1993): 961-987.

[8] Caselli, F., and J. Feyrer. "The marginal product of capital." The Quarterly Journal of Economics 122:2 (2007): 535-568.

[9] Ruggles, S., J. T. Alexander, K. Genadek, R. Goeken, M. B. Schroeder, and M. Sobek. Integrated Public Use Microdata Series: Version 5.0 [Machine-readable database]. Minneapolis: University of Minnesota, 2010.

[10] Clemens, M., C. Montenegro, and L. Pritchett. The Place Premium: Wage Differences for Identical Workers across the US Border. World Bank Policy Research Working Paper No. 4671, 2008.

[11] Shi, L. Chinese Household Income Project, 2002. University of Michigan Inter-University Consortium for Political and Social Research Dataset, 2009. Online at: https://www.icpsr.umich.edu/ icpsrweb/ICPSR/studies/21741

[12] Piyapromdee, S. The Impact of Immigration on Wages, Internal Migration and Welfare. University of Wisconsin Working Paper, 2014.

[13] Kennan, J., and J. R. Walker. "The effect of expected income on individual migration decisions." Econometrica 79:1 (2011): 211-251.

The full reference list for this article is available from the IZA World of Labor website (http://wol.iza.org/articles/freedom-of-movement-for-workers). 